\title{
DEPOSIT BASE OF COMMERCIAL BANKS AND WAYS OF STRENGTHENING IT
}

\author{
Zunnunova Khulkar Mukhtorovna \\ Uzbekistan, Tashkent, Tashkent financial institute, Teacher
}

DOI: https://doi.org/10.31435/rsglobal_ijite/01062018/5673

\section{ARTICLE INFO}

Received 19 April 2018

Accepted 23 May 2018

Published 01 June 2018

\section{KEYWORDS}

deposit, time deposit, savings,

transformation, capital,

security, deposit certificates,

saving certificates

(C) 2018 The Author.

\section{ABSTRACT}

The purpose of this topic is to study the deposit base, ways to increase them to increase the active operations and income of a commercial bank.

Introduction. One of the key pillars of the country's economy is - its robust and stable banking system. The level of socio-economic development and future development of each of the independent states depends, first of all, on the functioning of the banking system, which is being built and upgraded in that country. Effective management of commercial banks resources are crucial in increasing the volume of export-oriented goods and services in the country, ensuring the liquidity of banks and increasing the stability of the national currency, strengthening public confidence in the banking system. During the years of independence, our country has been developing and developing a two-tiered perfect banking system, as the services of the banks are changing and the cooperation with foreign banks has been improved.

However, some issues related to the banks' efficient use of resources and the sustainability of deposits remain topical in the modernization of the country's economy.

That is, it is necessary to create more favorable conditions for further strengthening of financial stability and reliability of the banking system, strengthening and development of the resource base of commercial banks ..." [1], the decision of the President of the Republic of Uzbekistan dated September 12, 2017 № PP-3270 On Measures for Further Development and Sustainability of the National Bank banking system.

The efficiency of commercial banks' lending operations can be ensured through the sustainability of their attracted funds. Strengthening the participation of commercial banks in longterm lending in the conditions of modernization of economy necessitates strengthening of their longterm resource base. In turn, the robustness of the resource base of the banks depends on the growth of the deposits of legal entities and population deposits, their size and durability.

Because the share of attracted funds in the structure of commercial banks' resources is quite high and their share is $70-80 \%$ [2]. In turn, ensuring the role of commercial banks in the sustainable development of the country's economy and increasing its activity in investment financing is directly related to the formation of their long-term resource base.

The ultimate goal of cardinal reforms in the banking and financial system of the country is to strengthen the resource base of commercial banks of the republic, increase the trust of business entities and population in the banking system.

The work on increasing the resource base of commercial banks ensures the growth of the total volume of bank deposits. In particular, this figure grew by $30.5 \%$ compared to 2015 and reached 28.5 trillion soums as of January 1, $2017\lceil 3\rceil$.

Research results. Deposit is cash or non-cash funds in national or foreign currency, which are held on client accounts in the bank specified in the contract terms and conditions of the use of the deposit, or without a specific term and returned to the customer in accordance with the legislation of Uzbekistan and the contract.

There is a classification of deposit operations. According to the method of execution, terms and the economic agents. The method of execution include personal deposits and bearer deposits. The economic agents include deposit of economic entities, deposit of individuals, deposit from other banks. Theoretically, 
due to the development of cashless circuits in the modern banking system, it is possible to transfer the initial formed deposits (either preliminary or real deposit required on the basis of cash issued by the Central Bank) to transfer from one bank to another without limitation, and to increase unlimited loan proceeds from commercial banks available. In the theory of foreigners, this process is called deposit multiplication (ie transfer of funds from one bank to another) and credit expanse.

The mandatory reserve requirements set by the Central Bank serve as an immediate restriction on deposit and credit expansion in the banking system. If it is assumed that there is no mandatory reserve, the multiplication of the deposit multiplier and loan exponent is equal to infinity and vice versa, the deposit multiplier will be 0 if the required reserve is $100 \%$.

The following mathematical formula can be used to calculate the maximum amount or limit of deposit (or credit) multiplication:

$$
D=D_{0} \frac{1}{R}
$$

where: D - maximal amount of the deposit that can be formed in the banking system;

Do - initial deposit;

$\mathrm{R}$ - liquidity reserve equal to deposit unit

In contrast to the compulsory reserve level, the degree of multiplier varies, which means that if the reserve requirement increases, the potential of the banking system will also decrease.

Table 1. On loans, deposits and common capital of commercial banks of the Republic of Uzbekistan [3] (trillion soums)

\begin{tabular}{|c|c|c|c|c|c|c|}
\hline Indicators & 2013 & 2014 & 2015 & 2016 & 2017 & Change in \% to 2017 in 2013 \\
\hline Credits & 11539 & 15652 & 20392 & 26500 & 34800 & 301,6 \\
\hline Deposits & 13200 & 18042 & 23725 & 26100 & 28500 & 215,9 \\
\hline Total capital & 4100 & 5334 & 6200 & 6500 & 6900 & 168,3 \\
\hline
\end{tabular}

According to the table data, as of January 1, 2017, the volume of commercial banks loans increased by 7.3 times, deposits - 7.4 times, total capital - 4.6 times.

Resources reflected in the bank's balance sheet are collected by the bank for high returns through lending, hedging securities and other types of banking operations. As we have seen in the preceding paragraphs, the bank's own capital and its equity capital are among the banking resources. Today, there are several reasons why the banking system needs a serious reform of the public deposit protection mechanism. The first group of reasons is natural-historically linked to the complexity of banking activities and the development of competition from the new traditional banking services market. As a result of the activation of the banks' establishment, the main types of banking services have grown and have become a competitive struggle for quality services, and not all banks can do so. At the same time, the banking business is becoming increasingly complicated. There are quite complex financial instruments in the market, which put very strict requirements to the bank staff. The second group of reasons has a clear historical character and is connected with deterioration of external conditions of banks activity. The economic downturn leads to a sharp increase in the risk of non-repayment of loans, due to the fact that companies are unable to pay for their payment. The payment crisis can lead to the banking sector and may put many credit institutions at risk. Especially, it is probable that banks dealing with industrial customers will suffer significant losses from returning loans.

Usually, in the advanced economic era, many commercial banks are set up by major businesses and industrial associations to solve their financial problems, in order to attract additional financial resources through the bank.

At present, we can address the following problems related to the stability of commercial banks' deposits:

1. One feature of the banks is that banks do their own business, rather than at their own expense, but at the expense of borrowed funds or attracted funds. In this regard, there is no constant control over the attracted funds of banks to ensure the stability of banks' deposits.

2. The insufficient attention was paid to strengthening the resource base of commercial banks by increasing the savings deposits.

3. The absence of a special system for daily monitoring of risk factors and liquidity imbalances and analysis of factors influencing changes.

4. Deposits of commercial banks are directly dependent on the bank's deposit policy. Basis for the implementation of the rational distribution of multilateral pricing and rational distribution of 
assets and liabilities of the bank, based on the attractiveness of the banking policy, which is the basis of the deposit policy elements, has not been clearly developed.

5. The value of all resources and the analysis of deposit transactions are not routinely performed while implementing the interest rate policy of a commercial bank.

6. Due to the disproportionality of the terms and interest rates of attracted deposits in ensuring stability of deposits.

7. It is necessary to develop a strategy aimed at ensuring the stability of deposits in commercial banks of our country.

In our view, elimination of the above mentioned problems and shortcomings will help to ensure the stability of the deposits of commercial banks of the Republic of Uzbekistan.

In order to ensure a high level:

- Development and approval of the mechanism of interest rates for commercial banks deposits, taking into account the recent level of inflation within the framework of attracted deposits and the decline in the refinancing rate of the Central Bank, as well as the stability of other macroeconomic indicators;

- Systematic critical analysis of deposit and interest rates of commercial banks: Determining the relationship between the terms of the revolving fund and the return on the bank's assets;

- Detection and elimination of unreasonable rates of interest rates on attracted deposits;

- Systematic critical analysis of savings and interest rates of commercial banks to determine the effectiveness of the use of attracted funds.

- Improving the regulatory requirements to commercial banks to implement deposit operations, including improving the structure and terms of attracting deposits of the population to reduce deposit risk, including potential risks to banks' financial stability.

As the measures taken to address the issues related to the stability of banks' deposits in the above-mentioned countries, we can point out the following:

1. For the purposes of establishing a permanent control over the attracted

funds of banks to ensure the stability of deposits of commercial banks:

- It is necessary to define a strategy ensuring stability of deposits. As part of this strategy, it is a marketing strategy that enhances the quality of deposits. In other words, in the era of crisis in the country 's economy, it is also examined that the customer will not lose confidence in the bank.

- It should be noted that the increase in the savings time deposits saves the balance of deposit balances;

- In the structure of resources attracted by banks, it is necessary not only to observe the stability of deposits, but also the source of deposit. According to the rating agency, in 2016, deposits of legal entities were more than twice the share of individuals. That is, if the share of individuals in total deposits is about co-ordination of credit resources and monitoring of lending numbers;

- The stability of deposits from other credit institutions should be assessed. It is known from the findings that the share of deposits from credit institutions in the structure of attracted funds of commercial banks of the republic has been increasing over the years. This reflects the sustainability of these deposits; 30 percent inviduals, about 70 percent of legal entities;

2. For the purpose of strengthening the resource base of commercial banks of the Republic of Uzbekistan by increasing the savings deposits:

- First, it is necessary to ensure a positive level of interest rates for savings deposits of legal entities;

- Secondly, it is necessary to ensure full and timely delivery of savings deposits by the commercial banks in cash.

In the above-mentioned proposal, economic instability, inflation, and high resource scarcity will help to revise the deposit policy of the banking system and other relationships with it. At the same time, the robust economic strength of commercial banks in the banking system of the country is crucial. It should be noted that the Bank's liabilities, which are under the depositary policy of the Bank, are of primary importance in banking practice. Of course, there are advantages and disadvantages of all banking instruments.

3. It is necessary to establish a special system for daily monitoring of risk and liquidity imbalances and analysis of factors influencing changes. Basically, the bank's strategic development policy is defined. Data base information can be used as a source for credit and deposit contracts, information on credit needs, information on accounts, and credit flows.

4. The database provides information on daily liquidity and solvency, and analyzes future prospects for banking operations. This will help to find a solution to the issues of placing funds, attracting resources, increasing their share of the bank, increasing the share of the bank in other institutions, developing new ways of earning money and developing new operations. The Bank's policy, which is the basis of deposit policy elements, is based on attracting resources as measures for multilateral pricing and rational distribution of assets and liabilities of the Bank as follows: 
- Creating favorable conditions for the Bank's deposit operations;

- moderate liquidity level of the bank;

- Introduce deposit types and various forms, including diversification instruments;

- Balance between deposit operations, ie managing periodic breakdowns between loans, deposits and loan disbursements in the form of pledged loan;

- Reduce free cash in bank deposit accounts;

- Conducting accurate interest rate policies;

- Implementation of measures to reduce the amount of interest expense on continuously attracted resources;

- Development of quality and culture among bank employees for the development of banking services in customer service.

5. In order to eliminate the problem of continuously increasing the value of all resources and analysis of deposit operations in the course of carrying out the interest rate policy of the commercial bank, it is necessary to:

- setting interest rates on deposits;

- study the dynamics of the interest rate on attracted resources;

- Calculation of real value of resources in conditions of inflation;

Current financial and economic analysis experts suggest that during the financial crisis, all commercial banks will be able to attract significant amounts of money from depositors and creditors over financial intermediaries.

The interest rate of the commercial banks of the Republic of Uzbekistan should be reduced by increasing the interest rates on time deposits. As a result, the share of time deposits in the total volume of commercial bank deposits and the amount of time deposits significantly increased. This is due to the fact that one of the main factors that increase the attractiveness of term deposit accounts for the population and enterprises is the rate of interest rates on time deposits.

However, in our opinion, it is necessary to reduce the interest rate by a sharp decrease in the reserve rate of the Central Bank, which is determined by the term deposits, as a result of which there is a significant difference between the mandatory reserve rate for mandatory deposits and the mandatory reserve rate of time deposits.

6. There is also a problem with the amount of funds attracted to improve the quality of banks' resources, which is of great importance. Because, if the banks attract long-term resources, they will be able to place these funds at a higher interest rate. This leads to the increase in banks' income. It is important to note, however, that if the banks attract short-term resources, the interest paid on these resources reduces the costs, but the short duration between these resources and the placement may not justify the bank's costs for the resources.

The attractive interest rate has a major impact on improving the quality of bank resources. The bank knows exactly the interest rate of attracted deposits for a certain period of time and creates an opportunity to place these deposits at a favorable interest rate.

7. In order to develop a strategy aimed at ensuring the stability of deposits in the commercial banks of our country, first of all, it is necessary to develop marketing that will enable customers to increase the attractiveness of their deposit accounts; Secondly, a system of indicators that characterizes the level of deposit sustainability should be developed; Thirdly, it is necessary to identify a group of clients that forms the basis of the deposit base for the bank and offer them a complex deposit service.

In addition to the above-mentioned measures, it should be noted that in order to ensure sustainable growth of deposits in banks, the media should continue to promote the system of established guarantees for the placement of funds of the population and business entities in bank deposits, created privileges and favorable conditions.

Conclusions. It is possible to conclude from ourse work the resources of each bank are important. Because, in order for the bank to implement its development strategy, it will certainly stabilize the resource base and improve its quality. We know that most of the bank's resources are attracted by means of attracting deposits. Therefore, banks seek to maintain their resource base at the optimal level and to ensure the stability of banks' deposits.

\section{REFERENCES}

1. Resolution of the President of the Republic of Uzbekistan dated May 6, 2015 № PP-2344 "On measures for further increase of financial stability of commercial banks and development of their resource base". Collection of the legislation of the Republic of Uzbekistan, 2015, No. 18, Art

2. Banking business. Express course: study guide / col. authors; Ed. O.I. Lavrushin. - 3rd ed., Pererab. and additional. - Moscow: Knorus, 2009.-352p.

3. Banking System: Positive Indicators, Responsibilities. January 16, 2017 www.cbu.uz 